\title{
Nesting behavior of Didelphis aurita: twenty days of continuous recording of a female in a coati nest
}

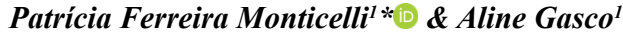 \\ ${ }^{1}$ Universidade de São Paulo, Faculdade de Filosofia, Ciências e Letras de Ribeirão Preto, Departamento de \\ Psicologia, Campus de Ribeirão Preto, Av. Bandeirantes, 3900, 14040-901, Ribeirão Preto, SP, Brasil \\ *Corresponding author: Patrícia Ferreira Monticelli, e-mail: patrimonticel@gmail.com
}

MONTICELLI, P. F.; GASCO, A. Nesting behavior of Didelphis aurita: twenty days of continuous recording of a female in a coati nest. Biota Neotropica. 18(3): e20180550. http://dx.doi.org/10.1590/1676-0611-BN-2018-0550

\begin{abstract}
Choosing the nest site to raise a litter has consequences on female fitness in mammalian species with no male participation in the parental care. We accidentally video recorded a coati's nest appropriation by a female opossum Didelphis aurita, at Parque Ecológico do Tietê, State of São Paulo, Brazil. For 29 days, from December 22, 2011, to January 19th, 2012, the activity of the female was video recorded 24h/day with a camera trap installed close to the nest. At her first appearance, she had infants in her pouch. After taking leaves to the nest twice on the first night, she kept a routine of going out after sunset and returning to the nest before dawn, carrying leaves on the tail on seven occasions. During the last days of recording, infants were seen attached to the female's body. Another episode of a female opossum with infants using a nest previously constructed by a coati was registered in 2013 . To our knowledge, this is the first continuous description of the daily activity of opossums during the nesting phase. Keywords: Nasua nasua, marsupial, nest appropriation, nidification, common opossum, parental behavior.
\end{abstract}

\section{Comportamento de nidificação de Didelphis aurita: vinte dias de gravação contínua de uma fêmea em um ninho de quati}

Resumo: A escolha de um ninho para criar uma ninhada tem consequências sobre o sucesso reprodutivo de fêmeas mamíferos que não compartilham com o macho o cuidado parental. Nós gravamos acidentalmente a apropriação de um ninho de quati por uma fêmea gambá Didelphis aurita, no Parque Ecológico do Tietê, São Paulo, Brasil. Durante 29 dias, de 22 de dezembro de 2011 a 19 de janeiro de 2012, a atividade da fêmea no ninho foi registrada 24h/dia. Em sua primeira aparição, ela tinha os filhotes ainda no marsúpio, e preparou o ninho, trazendo folhas para forração duas vezes na primeira noite. Depois, ela manteve uma rotina de sair após o pôr-do-sol e retornar ao ninho antes do amanhecer. Em sete dessas vezes ela trouxe folhas largas na cauda. Nos últimos dias, três filhotes foram vistos agarrados ao corpo da fêmea. Outra fêmea de gambá foi observada no PET usando um outro ninho de quati, em 2013. Esta é a primeira descrição contínua conhecida da rotina diária do comportamento de nidificação de gambás.

Palavras-chave: Nasua nasua, marsupial, apropriação de ninho, nidificação, gambá, comportamento parental.

\section{Introduction}

The Brazilian common opossum (Didelphis aurita Wied-Neuwied 1826) is a large marsupial species, smaller (body weight: 670-1800g; Cerqueira \& Lemos 2000) and less versatile than the big opossum $D$. albiventris, and a forest-dweller species of the Atlantic forest (Emmons 1997; Paglia et al. 2012). It is an insectivorous-omnivorous animal that forages mostly during the early hours of the night, and whose diet is composed of insects (in 100\% of collected feces, mainly Coleoptera, Diplopoda and Opiliones), solanaceous fruits (78\%) and vertebrates (59\%, primarily birds and mammals) (Cáceres \& Monteiro-Filho 2001). Females almost exclusively maintain home ranges of 0.2 ha, a seemingly defensible territory (Cáceres 2003), selected according to resource availability (Loretto \& Vieira 2005). The male home range is much more extensive (3.0 ha), and may vary in size during non-reproductive (larger) and reproductive seasons (smaller) (Cáceres \& Monteiro-Filho 2001; Loretto \& Vieira 2005).

The nesting behavior of didelphids is known for some species. For instance, the woolly mouse opossum (Micoureus demerarae) prefer to nest on a spiny palm tree of $4.66 \mathrm{ft}$, approx. $1.42 \mathrm{~m}$, in height, during daylight (Moraes Junior \& Chiarello 2005). D. marsupialis and D. albiventris both use shelters on the ground (during wet seasons), tree cavities or nests, also during the day (Sunquist et al. 1987; Vaughan \& Hawkins 1999; Astúa et al. 2015). Finally, the Brazilian mouse opossum (Monodelphis domestica) adopts a wooden box that it fills with paper and uses during daylight, in captivity (Unger 1982; Harrison 1985; Faden et al. 1986). 
All these species, and probably other didelphids, carry nest materials (dry leaves in nature or artificial material offered in captivity) to shelters that they opportunistically appropriate for themselves (i.e., dens of skunks and foxes, and nests of squirrels and birds: Vaughan \& Hawkins 1999; Cáceres \& Pichorim 2003; Loretto et al. 2005; Tortato \& Campbell Thompson 2006; Turrin \& Watts 2014). In some cases, nests are simultaneously used by didelphids and raccoons or skunks (Shirer \& Fitch 1970; Beisiegel 2006). Dark anthropogenic spaces may also be used as nests (e.g., trash bins, cement boxes on the floor, Astúa et al. 2015). These shelters may serve to avoid predators (Moraes Junior $\&$ Chiarello 2005), to protect the young (Fadem et al. 1986), and to regulate body temperature (Unger 1982; Fadem et al. 1986). Nests or dens in anthropogenic environments would be preferentially chosen by didelphids as they are not usually visited by wild predators, and they provide food and water sources (Krause \& Krause 2006).

Females with infants use the same nest for a longer period (Hossler et al. 1994; Allen et al. 1995) than males and non-reproductive females, and they fill it with more material (Fadem \& Swartz, 1986; Moraes Junior \& Chiarello 2005), evidently to hide infants from the time they exit the pouch until they are weaned (Fadem et al. 1986). In D. aurita, the fetus develops in the uterus for thirteen days, on average, after which they move to the pouch for the next 90 day developmental phase (Julien-Laferrière \& Atramentowicz 1990). The infants are then ready to live outside the mothers body for a further 15 days, and are left in the nest when female goes out foraging overnight. Finally, at their 118th day of life (Julien-Laferrière \& Atramentowicz 1990), the young may disperse from the natal nest and establish their home ranges, as suggested by their exploratory and moving behavior patterns (Julien-Laferrière 1995; Cáceres 2003).

Didelphis species, like other didelphids, were described as solitary (e.g., Cáceres \& Monteiro-Filho 2001; Loretto \& Vieira 2005), a hypothesis challenged by Astúa et al. (2015). Social behavior has only been studied in $D$. virginiana. In captivity and in the wild, they organize themselves in a hierarchical structure among males, positively correlated to body mass and testosterone concentration in plasma, and associated with scent-marking frequency and activity pattern, both of which are greater in higher status males (Holmes 1987; Ryser 1992). In nature, hours before the œstrus, females are followed by up to five males for several days (Ryser 1992). The same pattern was described in Philander opossum, the sister group of Didelphis (Guillemin et al. 2000).

\section{Material and Methods}

We describe here the nesting activity of a $D$. aurita adult female that we video recorded continuously for 20 days when monitoring coatis Nasua nasua nests at Parque Ecológico do Tietê (PET), State of São Paulo, Brazil. PET is a 1.400 ha area, composed of natural and exotic vegetation, artificial lakes, and a center for wildlife recovery and rehabilitation (Figure 1). There are dense populations of ring-tailed coatis and capuchin monkeys, and several bird species.

During the data collection campaigns that composed the Master Dissertation of AG, as we were interested in monitoring the nursing nests of coatis, we installed a camera trap (Bushnell trophy model 119436) in a Senna multijuga (Rich.) H.S. Irwin \& Barneby (Fabaceae, Caesalpinioideae). On November 25th, 2011, a security guard saw two adult coatis inside a nest in that tree, in front of the administration

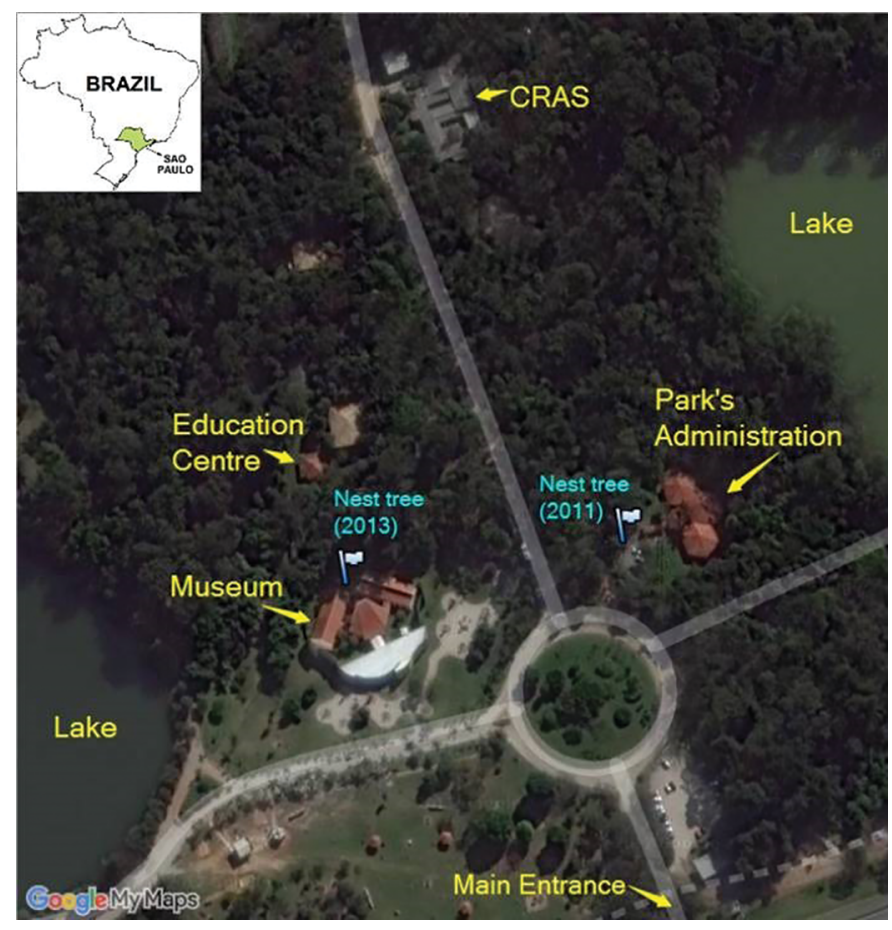

Figure 1. The position of the two trees, each containing a nest of ring-tailed coati appropriated by Didelphis aurita females in Parque Ecológico do Tietê, State of São Paulo, Brazil. The park was composed of artificial lakes, a center of wildlife reception and care (CRAS) and other facilities, such as the museum and the administration building. The distance between the two nest-trees was $214 \mathrm{~m}$.

building (Figure 1). On December 17th, the camera was installed and the recordings began at $15 \mathrm{~h} 07 \mathrm{~m}$. The appropriated nest was 7 meters above the ground in a 12 meter high tree of 1,570 m DAP (Figure 2 A-E), measured by a laser device (Rigid Micro LM-100) and an ordinary measuring tape. The camera trap was set to record for 30 seconds when triggered by movement. It did so until January 19th, 2012, when it was removed.

\section{Results}

The first observation of the opossum female occurred five days after camera installation, on December 22nd, 2011, at 23h58m (Figure 3). Table 1 shows the opossum activity during the following 29 days. On 7 out of 29 nights, she returned to the nest with dry leaves on tail, apparently for use as nesting material. The leaves were often broad. Two of these occasions occurred just after she appropriated the nest of the coatis (at $11 \mathrm{~h} 39 \mathrm{~m}$ on December $22 \mathrm{nd}$, and at $04 \mathrm{~h} 12 \mathrm{~m}$ on December 23rd). During the subsequent days, the female's activity followed a circadian pattern. She left the nest around 7 p.m., in the light phase (it was summer, a hot and rainy season in São Paulo, Brazil), and returned before sunrise, between 3 and 4 a.m. She always returned to the nest in the dark phase, until January 13th, 2012, when she came back after the sunrise (Table 1). Judging from the volume of her pouch (Figure 3), it is possible the when she first visited the nest, her infants were already in her pouch. To the extent of our knowledge, there is no information in the literature about the stage of the reproductive cycle in which didelphid females select a place to serve as a nursing nest. January 11 th, 2012, was when we first noticed the infants attached to the body of the mother (Figure 3), and they left the nest with her. So, that female and 


\section{Senna multijuga}
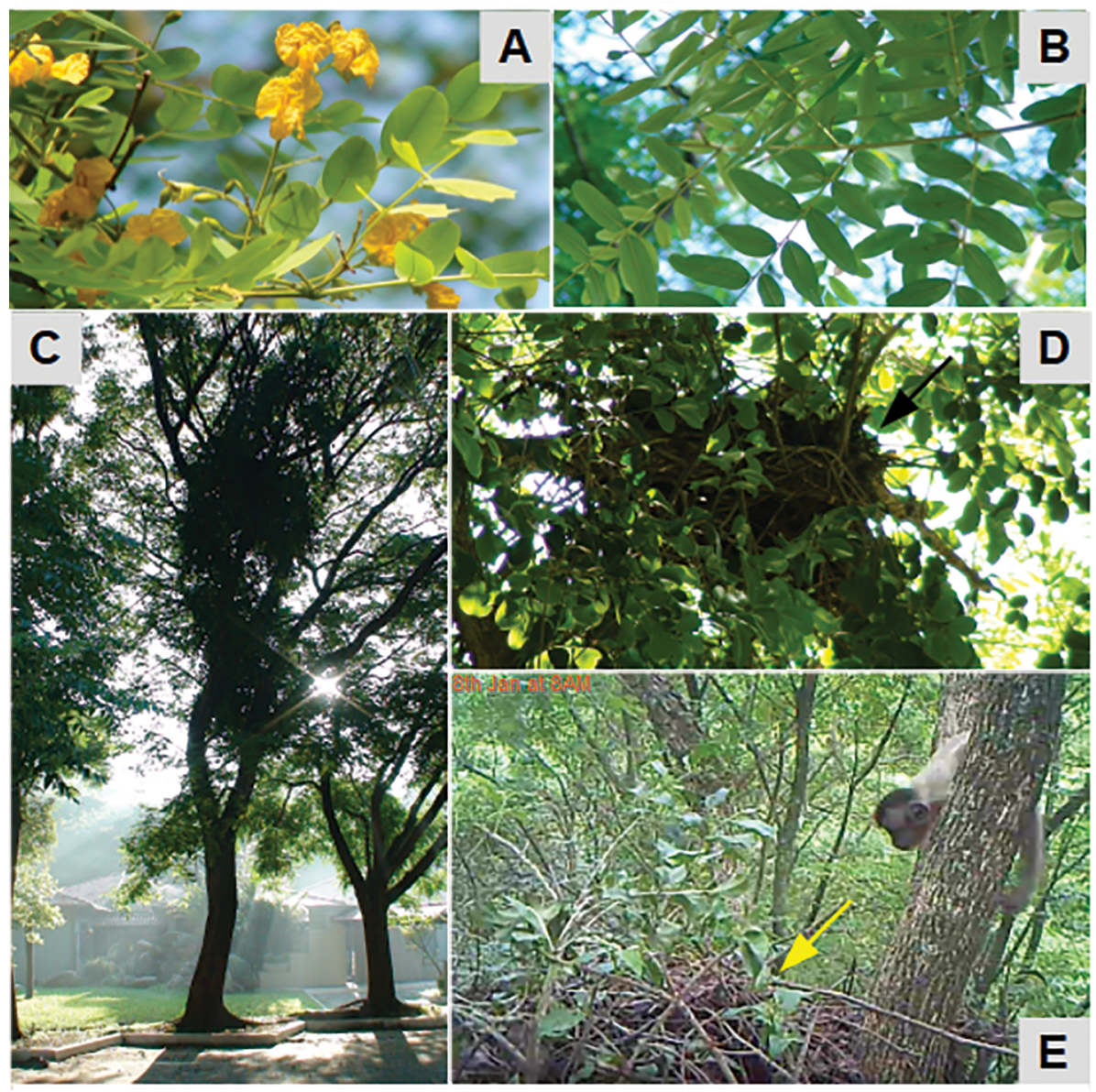

Syzygium cumini

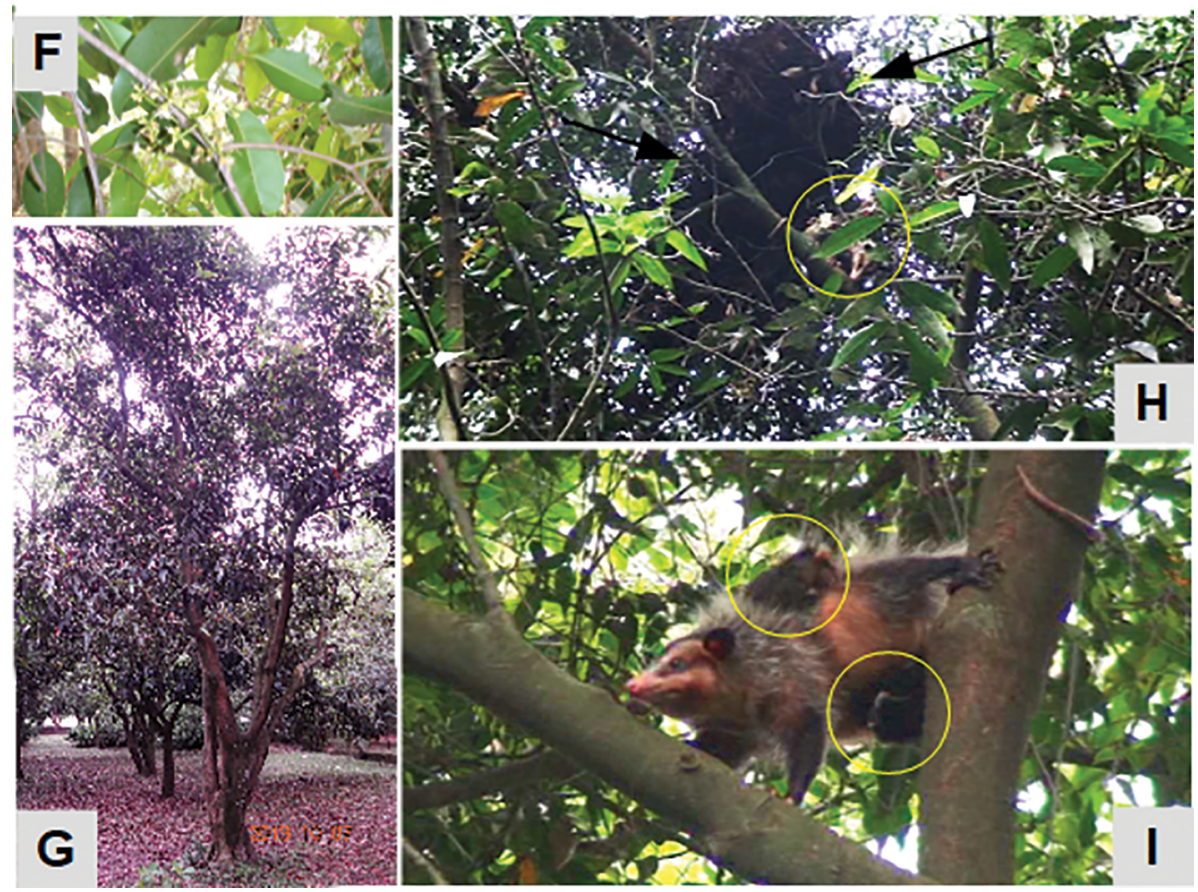

Figure 2. Details of two trees used by coatis to build nests, later appropriated by two females D. aurita in Parque Ecológico do Tietê: a Senna multijuga (A-E) and a Syzygium cumini (F-I), in 2011 and 2013, respectively. The first appropriated nest monitored (2011) is shown in D (from its bottom), and in E (overhead), when the camera registered the visit of a juvenile capuchin monkey. In 2013, a second female was seen coming out from a coati nest ( $\mathrm{H}$ and $\mathrm{I})$. 


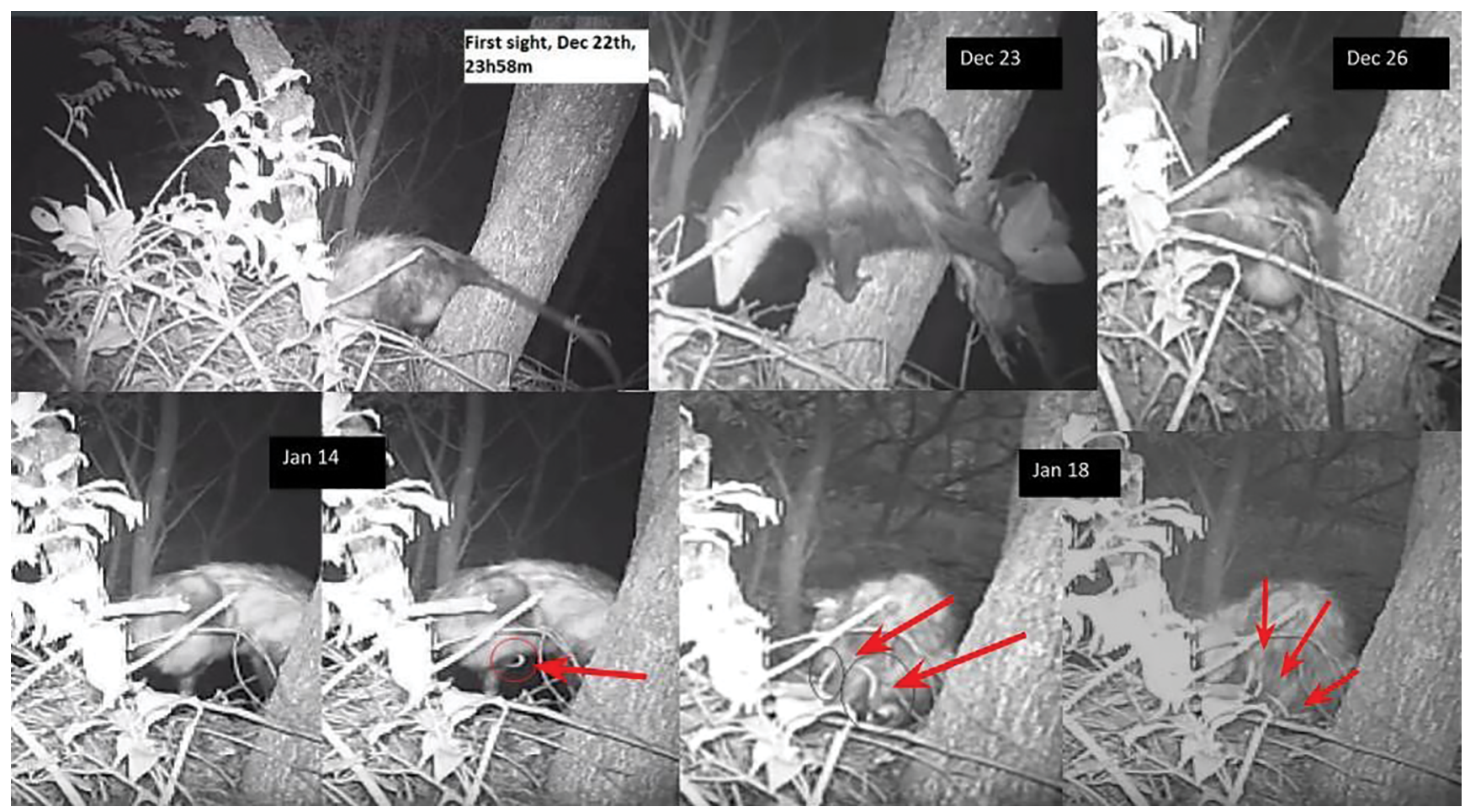

Figure 3. The nesting activity of the female opossum Didelphis aurita registered by a camera trap at Parque Ecológico do Tietê, in the city of São Paulo, Brazil. Her first appearance was on December 22nd close to midnight (top left). During that same night, she brought leaves on her tail (top middle). On December 26th, her pouch was voluminous. On the bottom, comparing the two consecutive photos taken on January 14th and 18th it is possible to see small tails moving against female's belly (red arrows) during grooming.

her offspring should not have reached that final stage of maternal care, in which nestlings are left in the nest during mothers' foraging activity, according to Julien-Laferrière \& Atramentowicz (1990).

We spotted another female opossum, two years later, entering a coati nest in PET. It occurred on October 5th, in 2013, at 01:30 p.m., in a Syzygium cumini (L.) Skeels (1912) (Myrtaceae, Figure 2 F-I, and Suppl. Material). AG had a video camera (Sony DCR-DVD610 mini DVD Handy cam Camcorder) and followed the female from the time she climbed up the tree with infants attached to her body until she entered the nest. After 15 minutes, she went down the tree carrying the infants on her back. That second nest was about 127 meters away from the first one (Figure 1).

\section{Discussion}

Our report, although opportunistic, is a relevant contribution to the knowledge of the nesting behavior of $D$. aurita. Like other opossums, the observed Brazilian opossum female took cover in an abandoned nest built by a different species, the coati Nasua nasua (Caceres \& Pichorim, 2003; Loretto et al. 2005; Tortato \& Campbell Thompson 2006; Turrin \& Watts 2014). The appropriation took place after the uterus developmental phase while infants were in the pouch.

In all the studied didelphids, nesting behavior was described as involving the transport of material on the tail. The opportunity of continuous recording provided the information about the frequency of nest improvement by the female. On the first night, when she first visited the nest (and presumably selected that place to be used as a nest), the female left and returned twice with leaves on her tail, and repeated this once more on the following day. Then the interval between nest material transport events increased ( 7 to a maximum of 11 days, Table 1). Unfortunately, the data does not indicate a precise association between the events of nest material transport and rainfall, lower temperatures or other environmental variables. For instance, the female returned to the nest with nest material on December 31st, 2011, a very wet day, but she did not do so on very windy days (January 2nd, 3rd, and 5th, 2012, when the camera trap fired several times during daylight).

To date, no one has ever seen opossums digging or folding branches to produce basket nests. Rather, all the literature offered describes of opportunistic appropriations of previously constructed nests, improved with collected material. If one considers improving appropriated nests with collected nest material as a nest-building behavior, it may be our contribution: to show that $D$. aurita females also construct nursing nests, as $D$. virginiana and $M$. domestica do, but not $D$. albiventris (Unger 1982; Fadem et al. 1986; Kimble 1997). Nevertheless, the behavior we describe here is very different from that of coatis (Gasco 2017). Coatis fold branches and straighten the leaves on the tree branches, stitching them all together and producing a basket (Gasco and Monticelli, in preparation). In addition, the juveniles carry materials to increase their nests.

Another contribution of our report relates to the nocturnal activity pattern of a female opossum during the pouch developmental phase. According to Caceres \& Monteiro-Filho (2001), D. aurita forages mostly during the early hours of the night. The observed female spent about 14 uninterrupted hours out of the nest, returning only before sunrise. Would she stay out for so long during the next developmental stage, when the infants are left in the nest during the mother's foraging activity? We would expect not, because of the infants vulnerability to predators. In $D$. virginiana, infants with 70 days of life, younger than 
Table 1. The activity of the female opossum in the video recordings taken from December 22nd, 2011 to January 19th, 2012. The last column shows when the female returns to the nest carrying leaves on her tail.

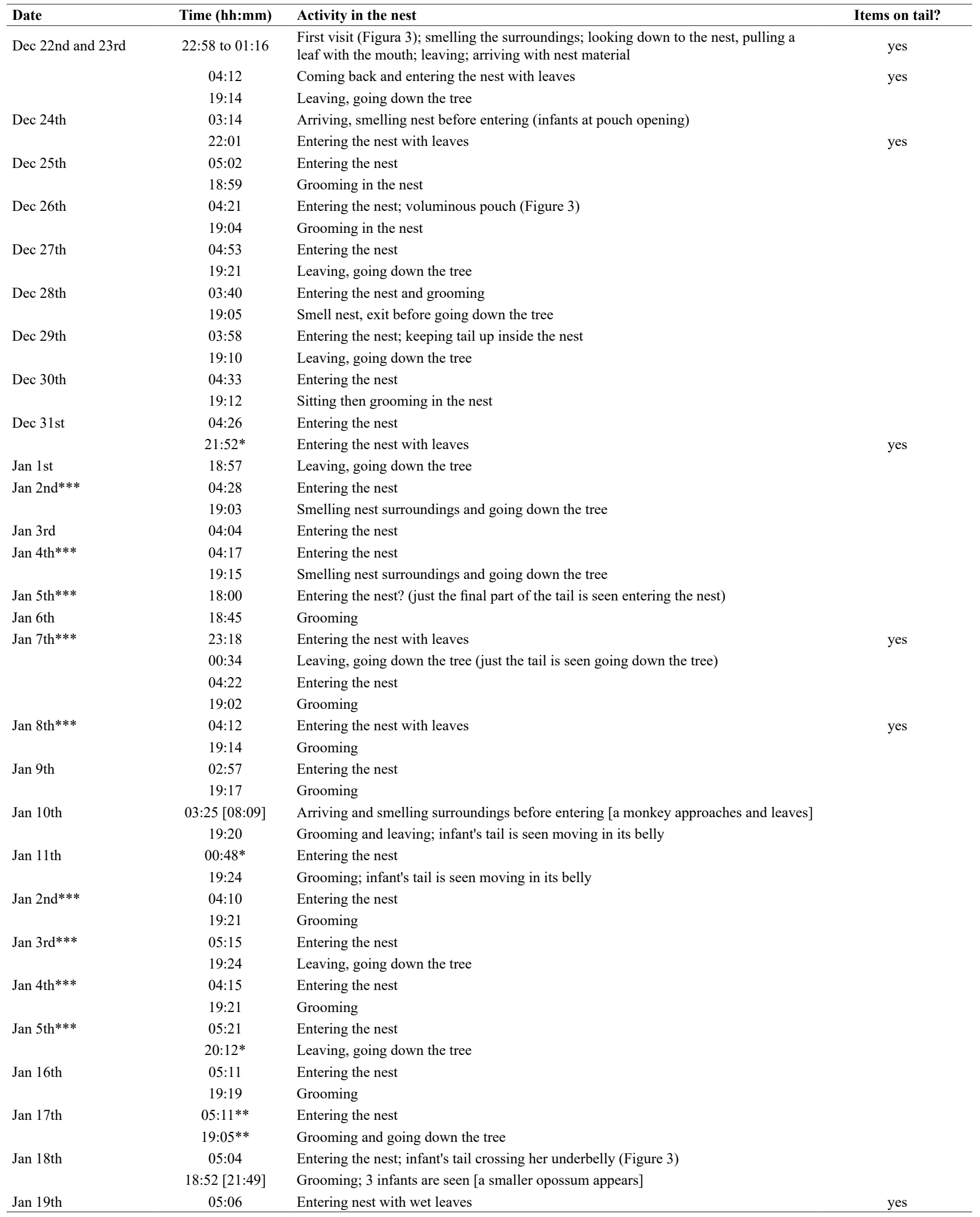

* Raining; ** Mistness; *** Wind. 
in $D$. aurita, are left in the den during the mother's foraging activity. After weaning (93-103 days, in $D$. virginiana), the young start to forage outside the shelter and $60 \%$ are hunted by predators (Hossler et al. 1994). At this time, the quality of the habitat (e.g., food availability and protective vegetative cover) surrounding the weaning site was shown to affect juvenile survival rate (Hossler et al. 1994). Unfortunately, we have no information about predation on opossums or the habitat quality. The selected nest, a coati's basket built at 12 meters high Senna multijuga in front of the administration building, could offer protection against terrestrial predators. In fact, it had been used previously by more than one coati female and in subsequent years.

\section{Supplementary material}

The following online material is available for this article:

Video: Nesting behavior of common opossum Didelphis aurita.

\section{Acknowledgments}

We are thankful to the director of Parque Ecológico do Tietê (PET) and the staff, especially to the BVSc. Liliane Milanelo, the BSc. Sayuri Fitorra, the employee Ronaldo, and the security employees. We are also thankful for help from the researchers MSc. Diana Borges, Ph.D. Mariana D. Fogaça, and MSc. Mariana M. Winandy, and especially to the BSc. Deborah de Barros who participated in the study of ring-tailed coati nests. Marcio P. Almada was essential in installing the camera trap on the nest-tree, and Professor Milton Groppo, head of the Herbarium of the Dept. of Biology FFCLRP, identified the arboreal species. This work was supported by the National Council for Scientific and Technological Development (CNPq).

\section{Author Contributions}

Patrícia Ferreira Monticelli: installing the trap camera (DATA COLLECTION), analyzing videos (DATA ANALYSIS AND INTERPRETATION) and writing (MANUSCRIPT PREPARATION).

Aline Gasco: installing the trap camera (DATA COLLECTION), analyzing videos (DATA ANALYSIS AND INTERPRETATION) and writing (MANUSCRIPT PREPARATION).

\section{Conflicts of interest}

The authors declare that they have no conflict of interest related to the publication of this manuscript.

\section{References}

ALLEN, C.H., MARCHINTON, R.L. \& LENTZ, W.M. 1985. Movement, habitat use and denning of opossums in the Georgia Piedmont. American Midland Naturalist, pp.408-412.

ASTÚA D., CARVALHO R.A., MAIA P.F., MAGALHÃES A.R, \& LORETTO D. 2015. First evidence of gregarious denning in opossums (Didelphimorphia, Didelphidae), with notes on their social behaviour. Biology Letters 11. DOI: 10.1098/rsbl.2015.0307
BEISIEGEL, B. M. 2006. Shelter availability and use by mammals and birds in an Atlantic forest area. Biota Neotropica 6(1): 0-0.

CÁCERES, N.C. 2003. Use of the space by the opossum Didelphis aurita WiedNeuwied (Mammalia, Marsupialia) in a mixed forest fragment of southern Brazil. Rev. Bras. Zoo. 20(2): 315-322.

CÁCERES, N.C., MONTEIRO-FILHO, E.L. 2001. Food habits, home range and activity of Didelphis aurita (Mammalia, Marsupialia) in a forest fragment of southern Brazil. Studies on Neotropical Fauna and Environment 36(2): $85-92$.

CÁCERES, N.C. \& PICHORIM, M. 2003. Use of an abandoned mottled piculet Picumnus nebulosus (Aves, Picidae) nest by the Brazilian gracile mouse opossum Gracilinanus microtarsus (Mammalia, Didelphidae). Biociências 11(1): 97-99.

CERQUEIRA R. \& LEMOS B. 2000. Morphometric differentiation between Neotropical black-eared opossums, Didelphis marsupialis and D.aurita (Didelphimorphia, Didelphidae). Mammalia 64: 319-328.

EMMONS L.H.F. 1997. Neotropical rainforest mammals: a field guide. Chicago: The University of Chicago Press.

FADEM, B.H. \& SCHWARTZ, R.A. 1986. A sexually dimorphic suprasternal scent gland in gray short-tailed opossums (Monodelphis domestica). J. Mammalogy 67:205-208.

KIMBLE, D.P., 1997. Didelphid behavior. Neurosc. \& Biobehav. Rev. 21(3): 361-369.

FADEM, B.H., KRAUS, D.B. \& SHEFFET, R.H. 1986. Nest-building in gray short-tailed opossums: Temperature effects and sex differences. Physiology \& behavior 36(4): 667-670.

GASCO, A.D.C. 2017. Os quatis sul-americanos Nasua nasua e os paralelos humanos: vida social e sonora, a cultura e os conflitos (Doctoral dissertation, Ribeirão Preto, Univ de São Paulo).

GUILLEMIN, M.L. 2000. Structuration spatiale et stratégies de reproduction chez deux marsupiaux Didelphidés de Guyane (Didelphis marsupialis et Philander opossum): Relation avec la structuration génétique des populations (Doctoral dissertation, Paris 13).

HARRISON, J.S .1985. Behavior and communication in the short bare-tailed opossum (Monodelphis domestica) (Doctoral dissertation, Virginia Polytec. Inst. and St. Univ.)

HOLMES, D.J. 1987. Social complexity and potential for chemocommunication in captive Virginia opossums, Didelphis virginiana Kerr (Doctoral dissertation, Bowling Green St. Univ.)

HOSSLER, R.J, MCANINCH, J.B \& HARDER, J.D 1994. Maternal denning behavior and survival of juveniles in opossums in southeastern New York. J. of Mammalogy 75(1): 60-70.

JULIEN-LAFERRIÈRE, D. 1995. Use of space by the woolly opossum Caluromys philander (Marsupialia, Didelphidae) in French Guiana. Canad. J. Zoo. 73(7): 1280-1289.

KRAUSE, W.J. \& KRAUSE, W.A. 2006. The opossum: it's amazing story. William Kraus.

JULIEN-LAFERRIÈRE, D. \& ATRAMENTOWICZ, M. 1990. Feeding and reproduction of three didelphid marsupials in two Neotropical forests (French Guiana). Biotropica, 404-415.

LORETTO, D. \& VIEIRA, M. V. 2005. The effects of reproductive and climatic seasons on movements in the black-eared opossum (Didelphis aurita WiedNeuwied, 1826). J. Mammalogy, 86(2): 287-293.

LORETTO, D., RAMALHO, E. \& VIEIRA, M. V. 2005. Defense behavior and nest architecture of Metachirus nudicaudatus Desmarest, 1817 (Marsupialia, Didelphidae). Mammalia mamm, 69(3-4): 417-419.

MORAES JUNIOR, E. A. \& CHIARELLO, A. G. 2005. Sleeping sites of woolly mouse opossum Micoureus demerarae (Thomas)(Didelphimorphia, Didelphidae) in the Atlantic Forest of south-eastern Brazil. Rev. Bras. Zool. [online], .22 (4):839-843 
PAGLIA AP, FONSECA GAB, RYLANDS AB, HERRMANN G, AGUIAR LMS, CHIARELLO AG, et al. 2012. Lista anotada dos mamíferos do Brasil/ Annotated checklist of Brazilian mammals. 2. ed. Arlington, Conservation International, 20.

RYSER, J. 1992. The mating system and male mating success of the virginia opossum (Didelphis virginiana) in Florida. J. of Zoo. 228(1): 127-139.

SHIRER, H.W. \& FITCH, H.S. 1970. Comparison from radiotracking of movements and denning habits of the raccoon, striped skunk, and opossum in northeastern Kansas. J.of Mammalogy 51(3): 491-503.

SUNQUIST, M.E., AUSTAD, S.N. \& SUNQUIST, F. 1987. Movement patterns and home range in the opossum (Didelphis marsupialis) J. of Mammalogy, Provo 68: 173-176.
TORTATO, M.A. \& CAMPBELL THOMPSON, E. R. 2006. Ocupação de caixas de nidificação por vertebrados de pequeno porte em área de Floresta Atlântica no sul do Brasil, e sua viabilidade de uso. Biotemas 19(2): 67-75.

TURRIN, C. \& WATTS B.D. 2014. Intraspecific intrusion at Bald Eagle nests. Ardea 102(1):71-8.

UNGER, K.L., 1982. Nest-building behavior of the Brazilian bare-tailed opossum, Monodelphis domestica. J. of Mammalogy 63(1): 160-162

VAUGHAN, C.S. \& HAWKINS, L.F. 1999. Late dry season habitat use of common opossum, Didelphis marsupialis (Marsupialia: Didelphidae) in neotropical lower montane agricultural areas. Revista de Biología Tropical 47(1-2): 263-269. 